\title{
Terbum
}

$29(2016) 297-319$

Ks. Andrzej Uciecha

\section{MOTYW ŚWIATEA I CIEMNOŚCI W mistyce Pseudo-Makarego}

The Motif of Light and Darkness

in the Mysticism of Pseudo-Macarius

Celem artykułu jest przybliżenie tematyki światła oraz jego roli w rozwoju dyscypliny ascetycznej i mistyki wczesnochrześcijańskiej na podstawie analizy tekstów wybranych z duchowej kolekcji Pseudo-Makarego (Symeona z Mezopotamii). Teologiczne przesłanie Symeona z Mezopotamii należy odczytywać w kontekście pneumatologicznym. W koncepcji Pseudo-Makarego odzwierciedla się tradycja duchowa nazwana przez badaczy une mystique pneumatique. Fundamentalną prawdą jego duchowych homilii jest komunia w Duchu Świętym i przyjęcie Jego pełni. Zasygnalizowane wątki apologetyczne pojawiają się w nauce Symeona na marginesie głównej tematyki i omówione są w artykule bardzo oszczędnie w kontekście ogólnej polemiki z herezjami.

\section{Abstract}

KEYWORDS

The aim of this article was to familiarize the Pseudo-Macarius; reader with the imagery of light, particularly

Pseudo-Makary; mistyka wczesnochrześcijańska; światło i ciemność; pneumatologia Symeon of 
its role in the development of ascetic discipline and early Christian mysticism. The vehicle for this exploration is an analysis of selected texts from the spiritual collection of the monk and hermit Pseudo-Macarius (Symeon of Mesopotamia). In Macarius's theology of light one may find clear references to the thought of Origen, as well as the influence of other Church writers representing the heritage of both Greek Alexandrian tradition and Syrian thought. The theological message of Symeon of Mesopotamia should be read in the pneumatological context. The fundamental truth of his spiritual homilies is communion in Holy Spirit and the reception of His fullness. In the article, the author seeks to elucidate and interpret the spiritual tradition known to researchers as une mystique pneumatique. The homilies of Macarius significantly contributed to the dissemination of this pneumatological mysticism throughout the Greek and later Byzantine world. The interesting apologetic themes appear on the margins of the main subject of the works and are very superficially discussed in the context of the general polemics with heresies.
Mesopotamia; early Christian mysticism; light and darkness; pneumatology

Wśród dzieł okresu patrystycznego, w których biblijna egzegeza i symbolika światła odgrywa istotną rolę w przekazie zbawczej prawdy, wymienić należy pisma Pseudo-Makarego. Ich autor, znany także jako Symeon lub Makary z Mezopotamii ${ }^{1}$, przewodził wspólnocie mnichów rozlokowanej na terenie Dolnej Mezopotamii pod koniec IV w. ${ }^{2}$ Owocem jego asce-

1 Por. Szczur, „Symeon z Mezopotamii”, 1308-1310.

2 Por. Pseudo-Macaire, Oeuvres spirituelles, I, 35. 
tycznego doświadczenia są liczne mowy, kazania, homilie, listy i sentencje zebrane w zbiorze greckich logo $i^{3}$. W'śród dotychczasowych opracowań i analiz poświęconych genezie i rozwojowi mistycznej teologii makariańskiej wymienić należy prace Vincenta Despreza i Antoine'a Guillaumonta ${ }^{4}$. W naszym artykule ograniczymy się do naświetlenia tylko tych aspektów i wątków nauczania mistycznego Makarego z Mezopotamii, w których pojawia się tematyka światła i ciemności, i to w takim ujęciu, które do tej pory było pomijane lub omówione tylko pobieżnie. Chcemy najpierw przybliżyć kontekst koncepcji antropologicznej, która - jak się wydaje - odgrywa istotną rolę w makariańskiej teologii, a w niej zwłaszcza poglądy dotyczące duszy. Spróbujemy zbadać kwestię oryginalności w funkcjonowaniu tych dwóch kategorii światła i ciemności jako sposobu przekazu wewnętrznych, a trudnych w opisie doświadczeń mistycznych. Interesująca jest także kwestia ewentualnego wykorzystania obrazu światła i ciemności w polemice antyheretyckiej. Źródłem badań będą wybrane fragmenty wyselekcjonowane w opublikowanych kolekcjach duchowych kazań i homilii Pseudo-Makarego.

3 Por. Pseudo-Makary/Symeon Egipski, „Homilia IV (49)”, 903. Jasiewicz podaje tam w przyp. 1 aktualną bibliografię źródeł i opracowań na temat życia i twórczości Pseudo-Makarego. Korekty wymaga błędna numeracja podana w zapisie Collectio I wydanej przez Bertholda, w Teil 1 zamiast Logoi 1-29, winno być 2-29.

4 Omówienie interesujących zagadnień pochodzenia, podobieństw i zależności mistyki i antropologii Pseudo-Makarego można znaleźć w opracowaniach znajdujących się w bibliografii podanej na końcu artykułu. Źródła, przekłady i opracowania: Collectio I; Collectio II; Collectio III; Collectio IV. Zob. też: Strothmann, Die syrische Überlieferung der Schriften des Makarios; Klostermann, Die slavische Überlieferung; por. Desprez, Poczatki monastycyzmu, II, rozdz. IX: Makary-Symeon (Pseudo-Makary), 121-187 (tam podano bibliografię tematyczną, s. 182-187); Guillaumont, Situation et signification, 311-322; Gribomont, „Macaire (Syméon)”, 1509-1510; Miquel, „Les caractères", 497-513; Pseudo-Macarius, The Fifty Spiritual Homilies; Maloney, Why Not Become Totally Fire?; por. Przeździecki, „Anapausis w pismach Pseudo-Makarego", 893-906. 


\section{Kontekst antropologicZny Mistyki MaKarego}

Zdaniem J.-P. Descheppera w porównaniu do bardzo intelektualnej teorii ascetycznej i mistycznej Ewagriusza z Pontu, skoncentrowanej na stoickiej koncepcji cnoty i niecierpiętliwości/beznamiętności, Makary rozwija mistykę światła, w której bliżej mu do teologiczno-antropologicznych idei Orygenesa ${ }^{5}$. Ta ogólnie sformułowana wskazówka uczonego wymaga wyjaśnienia. W celu rozwikłania tych niejasności proponujemy sięgnąć zarówno do komentarzy do księgi Pieśni nad Pieśniami, jak i homilii o tejże księdze, w których aleksandryjski egzegeta wyjaśnia znaczenie ukryte w interesujących dla naszego tematu określeniach „południe” i ,odpoczynek w południowy upał" oraz ich miejsce w opisie zagadnienia mistyki duszy:

„Południem” nazywa [Oblubieniec] owe tajniki serca, w których dusza od Słowa Bożego otrzymuje jaśniejsze światło wiedzy [...]. Teraz zaś, ponieważ szuka już czegoś doskonalszego i pożąda czegoś wyższego, prosi o południowe światło wiedzy ${ }^{6}$.

Orygenes pogłębia ten wątek duchowego poznania i uwarunkowań jego rozwoju. Następnie w swoim komentarzu przenosi się do opisu widzenia Boga, którego doświadczył Abraham pod dębami Mamre (por. Rdz 18,1). Podobnie jak patriarcha, każdy, kto „ujrzy światło umysłu, które w nim jest”, będzie miał „czyste serce, jasne i pełne blasku” i wtedy „okaże się, że ma w sobie południową porę [...], i dzięki temu czystemu sercu [...] zobaczy Boga”. Jak to miało miejsce w przypadku Abrahama, wymagane jest przebywanie „na zewnątrz namiotu”, czyli poza ograniczającą barierą cieles-

5 Por. Deschepper, „Pseudo-Macaire”, 270; por. Szczur, „Symeon z Mezopotamii”, 1309.

6 PG 13, 121C; Baehrens, Origenes Werke, 139; por. Orygenes, Komentarz do Pieśni nad Pieśniami, II, 4 [Orygenes, Komentarz, 88-89]. 
ności ${ }^{7}$. Ludzki umysł musi oderwać się od wszelkich cielesnych myśli i ludzkich pragnień. Tak opisany stan Orygenes nazywa i identyfikuje z doskonałą kontemplacją. W pełnym wewnętrznym oczyszczeniu człowiekowi nie przeszkadza już żadna cielesna siła, i tylko wtedy ludzka dusza może doświadczyć obecności Boga ${ }^{8}$.

Orygenes rozwija mistyczny temat duszy rozświetlonej „południowym światłem wiedzy”. W biblijnym porównaniu Oblubieniec zachęca duszę-oblubienicę, aby starała się poznać samą siebie ${ }^{9}$ :

Jeśli nie poznasz samej siebie, o piękna między niewiastami, jeśli za przyczynę swej urody nie uznasz faktu, że zostałaśstworzona na obraz Boży (por. Rdz 1,27), dzięki czemu masz tak wiele wrodzonej wiedzy, [...] każe ci wyjść, stanąć na końcu trzód i pasać już nie owce ani baranki, ale kozły, te mianowicie, które z powodu swej przewrotności i lubieżności „będą postawione po lewicy Króla” (por. Mt 25,33). [...] jeśli nie poznasz siebie samej, ujawnię ci również to, co jest największym złem [...]. Będziesz znosić taką sytuację dopóty, aż realnie i na własnej skórze przekonasz się, jak wielkim nieszczęściem dla duszy jest nieznajomość samej siebie i swego piękna ${ }^{10}$.

7 PG 13, 121D-122A; Baehrens, Origenes Werke, 139-140; por. Orygenes, Komentarz do Pieśni nad Pieśniami, II, 4 [Orygenes, Komentarz, 8990].

8 PG 13, 122B; Baehrens, Origenes Werke, 140; por. Orygenes, Komentarz do Pieśni nad Pieśniami, II, 4 [Orygenes, Komentarz, 90].

9 Wlg Pnp 1,7: Si ignoras te, o pulcherrima inter mulieres, egredere, et abi post vestigia gregum, et pasce hedos tuos juxta tabernacula pastorum.

10 PG 13, 123B-D; Baehrens, Origenes Werke, 141-142; por. Orygenes, Komentarz do Pieśni nad Pieśniami, II, 5 [Orygenes, Komentarz, 9192]; por. PG 13; PG 13, 45D-46B; Baehrens, Origenes Werke, 39-41; por. Orygenes, Komentarz do Pieśni nad Pieśniami, I, 8-9 [Orygenes, Homilie, 206-208]. 
Delficka maksyma gnothi seauton, świadomie i celowo przywołana przez Aleksandryjczyka ${ }^{11}$, znajduje tutaj swoją chrześcijańską adaptację i biblijną wykładnię. Słowa Oblubieńca to już nie zachęta, ale wręcz przestroga. Światło poznania jest darem Słowa, które jawi się jako konieczny warunek zjednoczenia z Oblubieńcem. Dzięki tej wiedzy dusza może rozpoznać najważniejszą prawdę o sobie samej, że została stworzona na obraz Boży. Aleksandryjczyk podaje i precyzuje możliwe sposoby, jakie pozwalają duszy poznać siebie $^{12}$. Wydaje się, że dla Orygenesa to poznawanie jest niekończącym się procesem oczyszczania się duszy i uwalniania z ciemności niewiedzy. Ten nieprzerwany cykl wewnętrznej przemiany ujęty został w obrazie ciągłego zbliżania się i oddalania duszy od Oblubieńca ${ }^{13}$. Zdaniem H. Crouzela w myśli Orygenesa światło jest najbardziej naturalnym symbolem łaski poznania; to Bóg jest źródłem światła, które pozwala poznawać to, co duchowe. Każda z Boskich Osób posiada swoje zadanie w udzielaniu tego światła: Ojciec jest Światłem; działa On za pośrednictwem Światła, którym jest Syn, Odbicie Światła Ojca. W Piśmie Świętym to Synowi przypisuje się takie świetliste tytuły (epinoiai), jak: Światło świata, prawdziwe Światło, Światło ludzi, Światło narodów, Słońce sprawiedliwości, wschodzące Słońce. Ten, kto przyjął Chrystusowe światło, sam staje się światłem. W życiu wiecznym to święci staną się światłem w „Słońcu sprawiedliwości”. Uczony dodaje, że Duch Święty nie jest nazywany Światłem, jednak i z jego osobą wiąże się działanie oświecające. W hierarchii epinoiai światło zajmuje czwarte miejsce po Mądrości,

11 Orygenes-Rufin mówi o „sentencji Chilona, jednego z siedmiu szczególnie sławnych mędrców greckich”, por. PG 13, 123B; w edycji W.A. Baehrensa jest tylko „Unius ex septem”, por. Baehrens, Origenes Werke, 141.

12 PG 13, 124A-D; Baehrens, Origenes Werke, 143-144; por. Orygenes, Komentarz do Pieśni nad Pieśniami, II, 5 [Orygenes, Komentarz, 92-93].

13 PG 13, 45BC; Baehrens, Origenes Werke, 39; por. Orygenes, Komentarz do Pieśni nad Pieśniami, I, 7 [Orygenes, Homilie, 206]. 
Logosie i Życiu. W Orygenesowym syntetyzującym ujęciu światło oznacza łaskę poznania i łaskę życia, która później zostanie nazwana łaską uświęcającą. Oba rodzaje łaski są nierozróżnialne $\mathrm{e}^{14}$.

Nie tylko Orygenesowa dusza rozświetlona „południowym światłem wiedzy” może stanowić punkt odniesienia w poszukiwaniach mistycznych inspiracji Pseudo-Makarego. Podobną antropologię znajdziemy w egzegezie Grzegorza z Nyssy. Ten uczeń wielkiego Aleksandryjczyka przejąt i rozwinął epistemologiczne sugestie swojego mistrza:

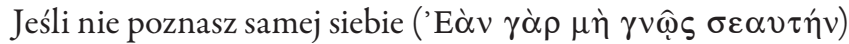
[...]. Ani niebo, ani księżyc, ani słońce, ani piękno gwiazd, ani nic innego widzianego w stworzeniu nie zostało stworzone na obraz Boży. Tylko ty jesteś wyobrażeniem natury przewyższającej wszelki umysł, podobieństwem niezniszczalnego piękna, odbiciem prawdziwego Bóstwa, odblaskiem prawdziwego światła - patrząc na nie, stajesz się tym, czym Ono jest, naśladując Tego, który jaśnieje w tobie dzięki promieniowi odbitemu w twojej czystości. Żadne inne stworzenie nie jest wystarczające wielkie, by mogło się mierzyć z twoją wielkością. [...] Jeśli więc znasz samą siebie, o piękna między niewiastami, wzgardzisz całym światem i zwrócisz oczy tylko na niematerialne dobro, nie będziesz zwracać uwagi na błędne ślady wydeptane w tym życiu ${ }^{15}$.

W porównaniu do innych Bożych stworzeń tylko istota ludzka wyposażona została w „tchnienie życia”, czyli duszę (por. Rdz 2,7). Wielkość duszy ma swoje źródło w akcie stworzenia na obraz Boży. Ten wyjątkowy atrybut pozwala tylko człowiekowi poznawać tajemnice ukryte i niedostępne

14 Por. Crouzel, Orygenes, 179-184.

15 Grzegorz z Nyssy, In Canticum Canticorum homiliae. Hom. 2 (PG 44, 805 CD. 808B); por. Grzegorz z Nyssy, In Canticum Canticorum (GNO 6) 68, 69; Grzegorz z Nysy, Homilie do Pieśni nad Pieśniami, 50-51. 
dla innych stworzeń. Zarówno dla Mistrza z Aleksandrii, jak i jego ucznia z Nyssy to w ludzkiej duszy koncentrowało się prawdziwe życie oraz poznanie jego źródła, czyli Stwórcy.

Zdaniem Crouzela często przeciwstawiano Orygenesa i Grzegorza z Nyssy, łącząc tego pierwszego z mistyką światła, tego drugiego zaś - z mistyką ciemności, co da się obronić pod warunkiem, że to przeciwstawienie nie ma charakteru absolutnego. Nie jest wykluczone, że na Orygenesową mistykę światła wywarła wpływ jego polemika z montanistyczną koncepcją transu jako stanu nieświadomego, podczas gdy nysseńska mistyka ciemności być może po części wypływa z reakcji Grzegorza przeciw neoarianizmowi Eunomiusza, który utrzymywał, że boską istotę całkowicie określa to, iż Ojciec jest niezrodzony. Nie da się też powiedzieć, że przeżycia mistyczne Grzegorza i Orygenesa aż tak bardzo różnią się, nawet jeśli inaczej są wyrażane. Poza tym mistycy czytają mistyków, tak więc owe tematy przechodzą z pokolenia na pokolenie, a kultura i doświadczenie każdego pokolenia wzbogacają je $\mathrm{j}^{16}$.

\section{Symbolika ŚWIATEA I CiemNośCi W ANTROPOLOGICZNO-PNEUMATOLOGICZNYCH WĄTKACH MISTYKI MAKAREGO}

Po prezentacji istotnych idei antropologicznych wielkich poprzedników Makarego, które stanowią - jak przypuszczamy - ważny kontekst naszych poszukiwań, przejdźmy do analizy poglądów tego mistyka. Stawiał on swoim słuchaczom trudne pytania: gdzie znajduje się dusza? W jaki sposób współpracuje ona z rozumem i inteligencją (vov̂s)? Kiedy i jak jednoczy się ona z Duchem Bożym, czy duchem świata? Do jakich wartości jest ona przywiązana i ku czemu się skłania? W jaki sposób szuka światła woli Bożej, aby

16 Por. Crouzel, Orygenes, 173-174. 
kochać Boga całym swoim sercem i całą swoją duszą (por. Mk 12,30) bez oglądania się na innych i nie szukając od-

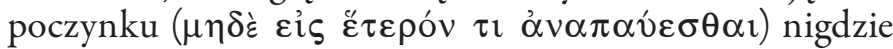

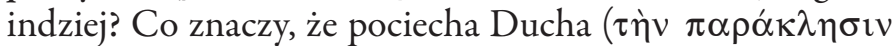
$\tau o \widehat{v} \pi v \varepsilon v ́ \mu \alpha \tau \circ \varsigma$ ) (por. Dz 9,31) jest dla niej prawdziwym odpoczynkiem ( $\alpha$ vó $\pi \alpha v \sigma \imath v \dot{\alpha} \lambda \varepsilon \theta \imath v \eta ́ v)$ ? Jak wzywać Pana w dzień i w nocy (por. Łk 18,7), aby odnaleźć zagubioną duszę i cieszyć się pokojem Chrystusa? ${ }^{17}$

Mnich z Mezopotamii tak wyjaśniał proces i mechanizmy poznawania tajemnic Bożej prawdy:

Błogosławiony Paweł, budowniczy Kościoła, zawsze dbały o prawdę, nie chcąc, aby uczniowie słowa byli powstrzymywani przez niewiedzę, wskazał dokładnie i jasno cel prawdy i umożliwił poznanie doskonałej tajemnicy chrześcijaństwa w każdej duszy wierzącej. Dzięki Boskiej energii dusza taka uzyskuje doświadczenie, ściślej odblask niebiańskiego światła Ducha w świętych duszach, poprzez objawienie i Jego mocą. (Paweł chciał), aby nikt, wyobrażając sobie, że oświecenie przez Ducha dokonuje się jedynie na drodze poznania idei, nie przechodził wskutek niewiedzy i niedbalstwa obok tajemnicy bardziej doskonałej łaski, ale raczej niech pozna z większą pewnością oświecenie duszy dane tym, którzy są tego godni, poprzez objawienie niepojętego światła niebiańskiego ${ }^{18}$.

Pseudo-Makary wyraźnie wskazuje na przemieniające działanie Ducha Swiętego, który rozświetla ludzką duszę nadprzyrodzonym światłem Boskiej energii. Uświęcenie duszy utożsamiane jest z mistycznym poznaniem i jednoznacznie łączy się z doświadczeniem Boskiego światła.

17 Por. III, 25,3,1 (SCh 275, 274) (oznaczenie lokalizacji tekstu źródłowego: pierwsza cyfra wskazuje na numer Collectio, druga - numer homilii; trzecia - podział na punkty).

18 I, 58,1 (GCS I/2, 182); por. Desprez, Początki monastycyzmu, 179. 
W teologii mistycznej Pseudo-Makarego widać wyraźne skoncentrowanie na znaczeniu i uświęcającej akcji Ducha

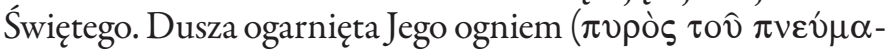
$\tau \mathrm{\alpha} \varsigma \tau \hat{\eta} \varsigma \zeta \omega \hat{\eta} \varsigma)$ zdobywa siłę i zdolność odrzucenia dzieł grze-

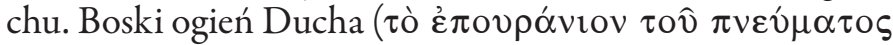
$\pi \hat{v} \rho)$ pozwala rozpalonej duszy nieustannie kochać Boskiego Oblubieńca i zapomnieć o całej marności doczesnego świata. Tylko w takim stanie dusza może przyciągnąć do siebie Boga, aby On w niej zamieszkał i królował, prowadził ją i w niej panowat. W opisie grzesznej duszy mistyk z Mezopotamii posłużył się obrazową analogią do ciała ogarniętego gorączką: choroba cielesna nie pozwala człowiekowi pracować. Dusza ogarnięta gorączką grzechu natrafia na podobną przeszkodę. Duchowa słabość powstrzymuje ją od dokonywania dzieł ży-

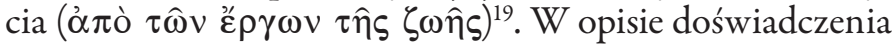
wewnętrznej przemiany, która dokonuje się w człowieku, Makary-Symeon chętnie i konsekwentnie używa terminologii psychologicznej (por. III,25,6) i obficie operuje obrazami zaczerpniętymi ze świata przyrody ${ }^{20}$. Łatwo zauważyć, ze nasz mistyk jest uważnym obserwatorem i analitykiem życia codziennego. Wydaje się, że wątek pneumatologiczny stanowi bardzo ważny, jeśli nie najważniejszy, komponent w doświadczeniu mistycznym Pseudo-Makarego. Z osobą Ducha Świętego wiąże się działanie oświecające, jednak jak to już zauważyliśmy u Orygenesa - Trzecia Osoba Trójcy nie jest nazywana Światłem.

Zapytajmy teraz o działanie Ojca i Syna. W opisie chrześcijańskiej doskonałości w swojej trzeciej Homilii nasz mistyk podkreśla zbawcze zaangażowanie Chrystusa, który pozwala wierzącemu panować nad namiętnościami, demonami i duchami nieczystymi. Pierwszy człowiek stał się ich niewolnikiem przez swoje nieposłuszeństwo. Chrystus-Oblubieniec (por. Mt 9,15) udziela mocy i przez chrzest przywraca człowieka

Por. III, 26,4,1-2 (SCh 275, 302).

20 Por. Pseudo-Macaire, Oeuvres spirituelles, I, 58. 
do jego pierwotnego stanu ${ }^{21}$. Chrześcijanin staje się nowym stworzeniem (por. 2 Kor 5,17) z innego świata; uczestniczy odtąd w nowej mądrości, ma nowego ducha, zdobywa inne bogactwa i nową godność, jego myślenie należy do Chrystusa, przemienia się w „syna światłości” (por. Łk 16,8; J 12,36), staje się „synem pocieszenia” (por. Dz 4,36) i „synem nowego przymierza" (por. Dz 3,25)22. W mistycznej myśli Makarego dostęp do tego nowego świata mają tylko chrześcijanie w pełnym tego słowa znaczeniu, czyli ci, którzy w Chrystusie stali się nowym stworzeniem. Oblubieniec znajduje upodobanie w tej duszy, która dzięki odwadze i cierpliwości zwycięsko pokonuje pokusy. W nagrodę Chrystus objawia się Oblubienicy w swoim pięknie i oświetla ją nieporówny-

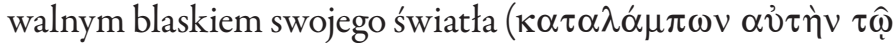

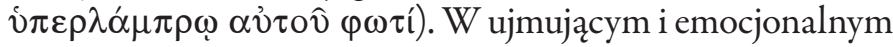
dialogu dusza jak oblubienica skarży się Oblubieńcowi, że pozostawił ją tak długo samą i naraził na ataki przeciwników (por. Pnp 5,7). W odpowiedzi Chrystus, pełen nieopisanego światła, ukazuje duszy znaki cierpienia, ślady gwoździ, biczowania, oplucia, swoje rany, i przekonuje o swojej wierności. Wszystkie cierpienia Oblubieniec podjął z miłości do oblubienicy i to dzięki Niemu dusza mogła wytrwać w przeciwnościach ${ }^{23}$. W ten sposób dusza może rozpoznać, że wszystkie dobre, które posiada, należą do Pana, pięknego i uroczego Oblubieńca (por. Pnp 1,16). W tym rozpoznaniu i dzięki niemu oddaje Mu się całkowicie (Pnp 2,6). Pseudo-Makary streszcza czułą rozmowę dwojga zakochanych w syntetyzującym podsumowaniu: Pan ukazuje się duszy w podwójnej postaci jako Oblubieniec cierpiący w swoich ranach i jako blask niewypowiedzianej chwały w swoim boskim świetle. W tym procesie asymilacji oblubienica ogarnięta blaskiem Oblubieńca przemienia się cała i staje się Jego chwałą za

21 Por. III, 1,2,1, (SCh 275, 76).

22 Por. III, 1,2,3 (SCh 275, 78).

23 Por. III, 3,2,1-2 (SCh 275, 88-90). 


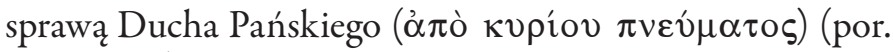
2 Kor 3,18). Dusza kontempluje nieustannie i naprzemiennie obraz Oblubieńca w jego cierpieniu i w Jego chwalebnym świetle. Symeon podkreśla raz jeszcze udział Ducha Świętego. W centralnym, jak się wydaje, punkcie swojej mistyki autor zaznacza, że w tej iluminacyjnej metamorfozie oblubienica jakby zapomina o swojej naturze, stając się duchem i mieszając się z Człowiekiem niebieskim i z Duchem Świętym

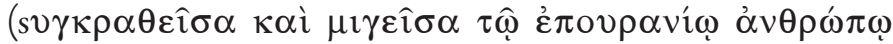

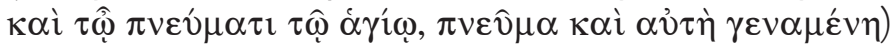
(por. 1 Kor 15,47-48) ${ }^{24}$. Sytuację oblubieńczej duszy można porównać do głodnego żebraka, który chodzi od drzwi do drzwi za "chlebem codziennym” (por. Jk 2,15) i nagle staje się królem, zapominając zupełnie o swojej biedzie. Tak też i dusza ubogacona bogactwem niebieskim nie pamięta już o dawnej biedzie. W mistyce Pseudo-Makarego Chrystus stanowi główny punkt odniesienia w duchowej przemianie i pozostaje najważniejszym wzorem do naśladowania. Mając boską naturę, Oblubieniec zapomniał w pewnym sensie o swojej godności, stając się jakby niewolnikiem podobnym do lu-

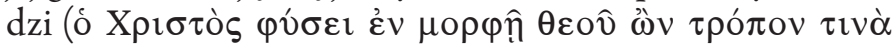

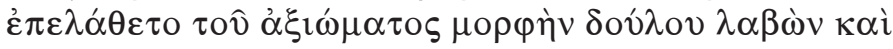

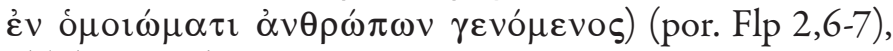
oblubieńcza dusza zaś, otrzymując istotę, moc i naturę Bożą

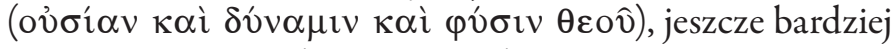
zapomina o swoim dawnym wstydzie ${ }^{25}$. Kończąc rozważania poświęcone naśladowaniu Chrystusa jako wzoru wytrwałości w doświadczeniach, nasz mistyk zachęca swoich uczniów, aby nie tracili nadziei ostatecznego wyzwolenia z ciemności. W perspektywie zmartwychwstania i wolności duchowej również ludzkie ciało doświadczone słabością zabłyśnie

24 Por. III, 3,3,1-2 (SCh 275, 90); podobne określenie zmieszania duszy

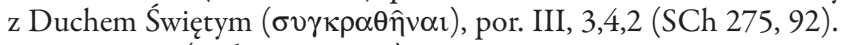

25 Por. III, 3,3,3 (SCh 275, 90-92). 
światłem, które ukrywa się w duszy. W ten sposób i dusza, i ciało człowieka zostaną uwielbione ${ }^{26}$.

Nad aspektem chrystologicznym dominuje idea wzrastania obecności Ducha Świętego w ludzkiej duszy i to w tym właśnie kontekście pneumatologicznym należy odczytywać teologiczne przesłanie Pseudo-Makarego. W jego duchowych Homiliach z całą wyrazistością przemawia mistyka, w której fundamentalną prawdą jest komunia w Duchu Świętym ${ }^{27}$ i przyjęcie Jego pełni ${ }^{28}$. Ten Duch rozpalony i rozpalający przynosi wewnętrzne ukojenie. W tym stanie człowiek może rozpoznać owoce Ducha ${ }^{29}$. W koncepcji Symeona odnajdujemy tradycję duchową syryjskiej mistyki. Dzięki tym Homiliom Makariańskim mistyka pneumatologiczna rozprzestrzeniła się w świecie greckim, a później bizantyjskim.

\section{Dusza JaKo ARENA WALKI ŚWIATEA Z CIEMNOŚCIAz}

W nawiązaniu do myśli Orygenesa i Grzegorza z Nyssy PseudoMakary charakteryzuje duszę jako piękne i cenne stworzenie Boga, który w niej mieszka i uczynił ją na swój obraz. Mistyk wielokrotnie podkreśla dobroć ludzkiej duszy i nigdy nie zaprzecza ani nie umniejsza jej godności. Równocześnie wyraźnie wskazuje on na niebezpieczeństwo realnego działania złych duchów w duszy tego, który grzeszył. Zło przychodzi z zewnątrz i nie jest wrodzone ludzkiej osobie stworzonej na obraz Boży, jednak jego szkodliwe działanie przenika wszystkie części ludzkiego ciała, duszy i ducha ${ }^{30}$. Wnętrze człowieka $(\kappa \alpha \rho \delta i ́ \alpha)$ podobne jest do wazy, która zawiera wszelakie ułomności, ale znajdują w niej także miejsce Bóg, aniołowie,

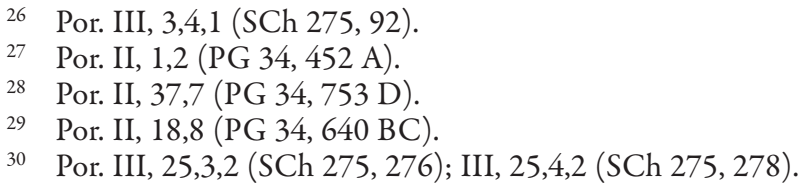


życie, królestwo, światło ( $\varphi \hat{\omega} \varsigma)$, apostołowie i skarby łaski ${ }^{31}$. To przekonanie wydaje się pochodzić z nauczania św. Pawła, który opisywał swoją bezbronność wobec prawa grzechu

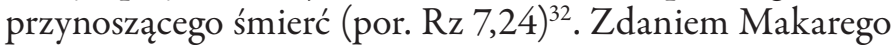
myliłby się ten, kto uważałby, że dusza jest mała, tak jak małe jest ciało, w którym się znajduje. Dusza bowiem wykracza poza ograniczenia cielesności dzięki swojej naturze duchowej i niematerialnej. Wyrazem jej dominacji nad mikroświatem ciała są myśli i wyobrażenia. Mistyk nazywa ten antropologiczny aspekt duszy obrazem, ale natychmiast dodaje, że prawdziwą ikoną Boga jest właśnie dusza. Pozostaje ona niewidzialna i niezbadana dla niej samej z powodu zasłony zła.

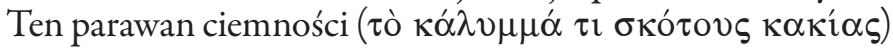
okrywa ludzką duszę od chwili przestępstwa Adama i przechodzi z pokolenia na pokolenie na każdego człowieka. W konsekwencji dusza straciła możliwość kontemplacji swojego Stwórcy, nie potrafi już radować się światłem Jego chwały i dobra, nie odnajduje w Nim życia i pocieszenia, ani nie doznaje rozkoszy miłości Pana ${ }^{33}$. Makary nie jest tylko mistykiem serca: intelekt (vô̌s) odgrywa istotną rolę w jego antropologii ${ }^{34}$. Mimo swej uciążliwej ułomności dusza w swej naturze pozostaje dziełem kompletnym i nie traci obrazu in-

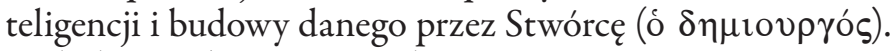
W kolejnej obrazowej analogii Symeon stara się wyjaśnić skomplikowaną sytuację duszy ogarniętej zasłoną ciemności. Jej stan przypomina człowieka zamkniętego w więzieniu, w którym nie ma ani drzwi, ani okien, ani żadnego wyjścia. Więzień może tylko wołać na pomoc tych, którzy są na zewnątrz więzienia. Podobnie dzieje się z duszą oddzieloną od

31 Por. II, 43,7 (PG 34, 776); Pawłowy termin „waza”, „naczynie” ('ُ

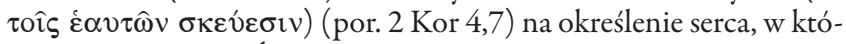
rym mieszka Duch Święty, por. III, 25,6,3 (SCh 275, 288).

32 Por. Pseudo-Macarius, The Fifty Spiritual Homilies, 277.

33 Por. III, 26,4,3-4 (SCh 275, 302-304); na temat przestępstwa Adama, por. III, 25,2,2 (SCh 275, 272).

34 Por. Pseudo-Macaire, Oeuvres spirituelles, I, 304, przyp. 1. 
Boga zasłoną namiętności ( $\alpha \lambda \lambda \hat{u} \mu \mu \alpha \tau \imath \pi \alpha \theta \hat{\omega} v)$ i zamkniętą w więzieniu ciemności grzechu; mimo tej wady pozostaje w swojej głębi nietknięta $\mathrm{w}$ takim stanie, w jakim została stworzona; dusza nie utraciła zdolności refleksji, medytacji i pragnienia życia w świetle; ciągle może prosić o pomoc Tego, który jest na zewnątrz więzienia grzechu. Słysząc to wołanie i widząc w nim wiarę i miłość duszy, Wyzwoliciel

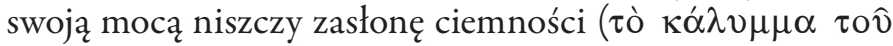
$\sigma \kappa o ́ \tau o v \varsigma)$, rozświetla duszę swoim światłem, uwalnia ją z ciemności grzechu namiętności i prowadzi ją według swojej woli. Dusza, która znajduje się wewnątrz tej zasłony, zwraca swoje myśli i pragnienia ku Panu. Odrzuca ona wszystko to, co widzialne, i z wiarą oddaje się poszukiwaniu niewidzialnej

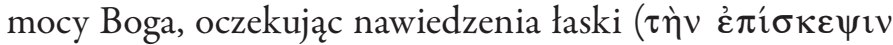
$\tau \hat{\eta} \varsigma \chi \alpha \dot{\alpha} \rho \imath \varsigma_{\text {). }}$. Pan nie pozostaje obojętny na wołanie duszy, ukazuje się jej i wspomaga posiłkiem duchowym, aby mogła całkowicie wypełniać Jego wolę (por. J 16,13) ${ }^{35}$. Zakochana dusza i jej Wyzwoliciel stają się jednym duchem (por. 1 Kor 6,17), jedną myślą i stapiają się w jedno ${ }^{36}$. Dusza przemienia się w świątynię wypełnioną blaskiem Bożej chwały. Pseudo-Makary swobodnie posługuje się metaforami zaczerpniętymi od św. Pawła (por. 1 Kor 6,16) i z terminologii stoickiej ${ }^{37}$.

Istotnym elementem teologii i myśli antropologicznej w nauczaniu Makarego-Symeona jest koncepcja antynomii zła i łaski. Te dwie przeciwstawne „rzeczywistości” walczą w ludzkiej duszy i rozwijają się jak dwie osoby (prosopa) w procesie dynamicznego antagonizmu. Makary celowo wykorzystywal to obrazowe przedstawienie w swojej polemice z uproszczeniami i błędami mesalianizmu ${ }^{38}$. Nasz mistyk

35 Por. III, 26,5,1-3 (SCh 275, 304-306); por. także I, 4,9,3 (GCS I/1,

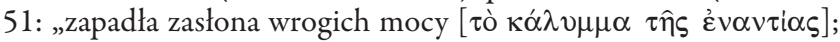
[światło] jaśnieje tylko częściowo").

36 Por. III, 26,6,1 (SCh 275, 306).

37 Por. Desprez, Początki, 178.

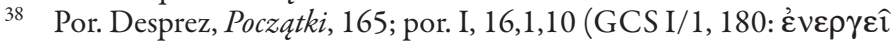

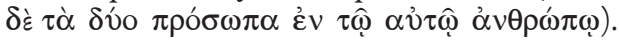


tworzy obraz dwóch światów, które nazywa ousia światła

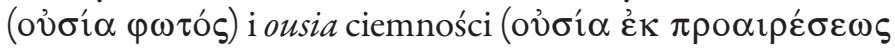

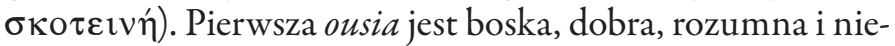
materialna, oznacza Boga, druga ousia powstaje z wolnego wyboru i określa duchy błądzące (por. $1 \mathrm{~J}$ 4,6) i księcia tego świata (por. J 12,31). Boska ousia światła, zwana także ousia Ducha ${ }^{39}$, chroni duszę od choroby pożądania, pozwala rozpoznać prawdę i wypełnić wszystkie święte przykazania. Dusza musi jednak ciągle na nowo podejmować trud uwalniania od panowania władzy przewrotnej ciemności $(\operatorname{Kol} 1,13)$, od duchów złych (por. Ef 6,12), od złośliwego pożądania ${ }^{40}$. Jednym z obrazowych wyjaśnień tego konfliktu jest przykład troskliwego i nieustannego podsycania ognia, który podgrzewa garnek z jego zawartością. Bez dokładania drew ogień słabnie i gaśnie. Podobne zjawisko można zauważyć w życiu

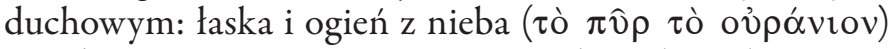
znajdują się zarówno we wnętrzu człowieka, jak i na zewnątrz. Podtrzymywanie modlitwy to dokładanie drewna. Myśli stają się ogniem i zatapiają w Bogu, zło zaś wycofuje się na zewnątrz. Jednak wskutek zaniedbania i trosk tego świata grzech wraca i opanowuje człowieka. Dusza zaczyna się dręczyć i tęsknić za utraconym wypoczynkiem, skarży się i błaga, w ten sposób wraca do Boga i odzyskuje upragniony odpoczynek. Żar duszy rozpala coraz większy ogieńn ${ }^{41}$. W tej nieustannej walce uczestniczy nie tylko Bóg, ale także Jego stworzenia. Makary wymienia aniołów i święte moce

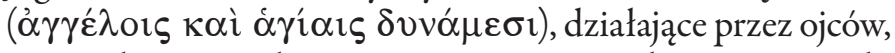
patriarchów, proroków, samego Pana, apostołów i nauczycieli. Misja wskazanych wysłanników Boga polegała w istocie na odkrywaniu prawdy i woli Bożej oraz doprowadzeniu duszy do życia wiecznego. Wrogiem duszy w realizacji tych Bożych

\footnotetext{
39 „ousia upragnionego piękna i niewyobrażalnego światła Bożego Ducha", por. III, 25,2,4 (SCh 275, 272-274).

40 Por. III, 25,2,1-2 (SCh 275,270-272).

41 Por. I, 4,5,1-2 (GCS I/1, 45).
} 
planów jest szatan, potęgi i moce zła, których posłami są fałszywi prorocy i przewrotni apostołowie, gorszyciele i oszuści oraz herezje (por. 2 Kor 11,13). Mistyk używa Janowej terminologii i wskazuje na Antychrysta, który nieustannie usiłuje pokonać duszę oraz stara się pogrążyć ją na zawsze w ciemnościach potępienia ( $\dot{\varepsilon} \nu \tau \hat{\omega} \sigma \kappa o ́ \tau \varepsilon \imath ~ \tau \hat{\eta} \varsigma \kappa \alpha \tau \alpha \kappa \rho i ́ \sigma \varepsilon \omega \varsigma)$ i w otchłani złych mocy ${ }^{42}$.

W narracji ostatecznej walki światłości z ciemnością Symeon nie pomija charakterystyki iluminacyjnej. W hymnie uwielbienia Stwórcy, który przybędzie w dniu sądu jako słońce nieprzystępne, łaska Jego najświętszego Ducha lśnić będzie jak gwiazda nad sprawiedliwymi. Wtedy wszyscy zostaną oświeceni, każdy na miarę swojej wiary i swych uczynków, swej nadziei i swej miłości, na miarę oczyszczenia i uświęcenia przez Ducha Bożego ${ }^{43}$. Dusza, która jako Oblubienica wytrwale poszukiwała światła Oblubieńca w świecie doczesnym i została uwolniona przez Ducha z zasłony ciemności, gwarantuje swemu ciału udział w światłości wiecznej (por. Flp 3,21) ${ }^{44}$.

\section{WALKA PRAWDY Z BŁĘDAMI HEREZJI}

Na liście przeciwników duszy znalazły się też herezje. Musimy jednak wyraźnie zaznaczyć, że w opisach demaskowanych i potępianych błędów trudno znaleźć porównania i obrazy ciemności. Charakterystyczne, że Symeon bardzo rzadko i oszczędnie podejmuje wątek fałszywego nauczania. W jego

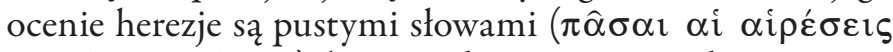

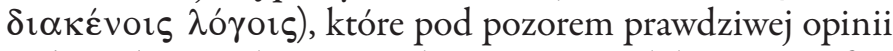
żądają, aby je traktowano jako uczciwe. Ta lakonicznie sformułowana charakterystyka przeciwnika stanowi jedynie tło i punkt wyjścia do zaprezentowania istoty chrześcijańskiej

\footnotetext{
42 Por. III, 25,4,2 (SCh 275, 278).

43 Por. I, 27,5 (GCS I/1, 245).

44 Por. I, 58,2 (GCS I/2, 184).
} 
prawdy i wiary. Ukazuje się ona w uczynkach dzieci Kościoła Chrystusowego, w działaniu Bożego Ducha, który zstępuje i okrywa swoim cieniem ich dusze. To jego łaska sprawia, że rodzą się w nich godne owoce (por. Łk 3,8) z mocą, oddaniem i pełną świadomością; dzięki Jego działaniu w wewnętrznym człowieku (por. Rz 7,22) i we wnętrzu jego serca (por. $1 \mathrm{P}$ 3,4) dokonuje się odnowienie myślenia, przemiana i rodzi się nowe stworzenie. Na tym polega prawdziwe chrześcijaństwo

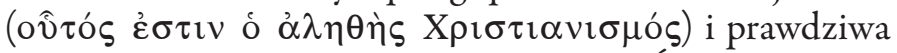
tradycja apostolska, przekazana w Piśmie Świętym, i taka jest nadzieja tych, którzy prawdziwie wierzą w Chrystusa

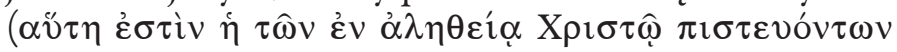
$\left.\dot{\varepsilon} \lambda \pi^{i} \varsigma\right)^{45}$. Podkreślamy z naciskiem, że użyte tutaj słownictwo posiada charakter wyraźnie apologetyczny i antyheretycki. To

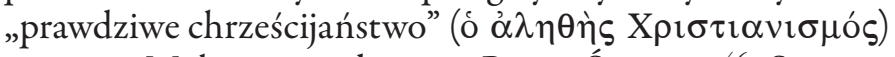
w ujęciu Makarego rodzi się z Pisma Świętego ${ }^{46}$. Symeon z Mezopotamii rozwija wątek powstawania i rozwoju herezji w kontekście tematyki poznawania Bożych tajemnic. Jego zdaniem herezje rodzą się z powodu lekceważenia prawdy o niepoznawalności Boga. W apologetycznym wywodzie Mistyk uzasadnia, że wszelkie słowne debaty i zaufanie do nauki nie przynoszą duszy żadnych korzyści, a jedynie szkodę

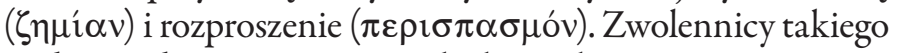
podejścia do sprawy są niewolnikami, którzy przypominają

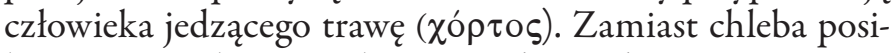
lają się oni pokarmem, który nie daje żadnej przyjemności jedzenia ani organizmowi energii. Podobni są oni także do człowieka, którego sylwetkę namalowano na ścianie. Obraz takiego osobnika jest kompletny, ale nie porusza się. Od samego początku wszystkie herezje powstają z powodu ulegania pokusie zamknięcia mądrości Bożej w ludzkich słowach.

45 Por. III, 25,6,2, 286; na temat działania Ducha Świętego wyrażonego w określeniu „okrywa swoim cieniem”, por. SCh 275, 286-287, przyp. 2.

46 Por. SCh 275, 287, przyp. 3. 
Prowadzą one na manowce ( $\dot{\varepsilon} \pi \lambda \alpha \nu \eta \dot{\theta} \eta \eta \sigma \alpha)$ ), odrzucając mądrość św. Pawła (por. Rz 11,33-34) i prawdę o niepoznawalności Boga. Zarówno nauczyciele herezji, jak i ich uczniowie nie chcą uznać swojego błędnego myślenia. Należy pamiętać, że Bóg objawia się w Piśmie Swiętym na różnych miejscach i w różny sposób. Makary przestrzega słuchaczy przed przesadnym zaufaniem do precyzyjnych definicji, obrazów i pojęć Boga, gdyż On wymyka się im wszystkim. Ujęcie Pseudo-Makarego nie jest dokładnym odpowiednikiem teologii symbolicznej Grzegorza z Nyssy. Nasz mistyk pozostaje wierny obrazowości biblijnej. W jego metodzie argumentacji można rozpoznać ślady stoicyzmu i wpływ mentalności pisarzy syryjskich ${ }^{47}$. W dowodzeniu naszego apologety warto podkreślić metodę opisywania, w której nigdy nie mówi o heretykach, ale o herezjach.

\section{ZAKOŃCZENIE}

W niniejszym artykule chcieliśmy przybliżyć tematykę światła oraz jego rolę w rozwoju dyscypliny ascetycznej i mistyki wczesnochrześcijańskiej na podstawie analizy tekstów wybranych z duchowej kolekcji Pseudo-Makarego. Teologiczne przesłanie Symeona z Mezopotamii należy odczytywać w kontekście pneumatologicznym. W koncepcji naszego autora odzwierciedla się tradycja duchowa nazwana przez badaczy une mystique pneumatique. Fundamentalną prawdą jego duchowych Homilii jest komunia w Duchu Świętym i przyjęcie Jego pełni. W opisie duchowej przemiany Makary chętnie posługuje się terminologią psychologiczną. Mistyk w sposób twórczy i dyskretny przejmuje i rozwija teologiczno-antropologiczne dziedzictwo swoich Mistrzów. Tak jak twierdził Orygenes i Grzegorz z Nyssy, dzięki wyjątkowej pozycji w dziele stworzenia na obraz Boży, człowiek ma zdolność

47 Por. III, 22,1,1-2, 254; por. SCh 275, 256-257, przyp. 2. 
poznawania tajemnic ukrytych i niedostępnych dla innych stworzeń. Zasygnalizowane wątki apologetyczne pojawiają się w nauce Symeona na marginesie głównej tematyki i omawiane są bardzo oszczędnie w kontekście ogólnej polemiki $\mathrm{z}$ herezjami.

$\mathrm{Z}$ uzasadnionym zdziwieniem należy ocenić brak jasno sprecyzowanych propozycji w adaptacji wzniosłych ideatów ascetycznych i mistycznych. Tak wytrawny nauczyciel i mistrz życia duchowego w swoisty sposób zachęcał swoich uczniów do wnikliwego osądu myśli. Stawiał im niebanalne i trudne pytania w ramach egzaminu, który określilibyśmy jako rachunek sumienia albo fragment reguły zakonnej. Bez wątpienia Makary-Symeon jest „mistrzem światła”, nawet jeśli jego temat przejścia odpowiada fazie negatywnej „mistyków ciemności”. Nie podaje on zasad surowej etyki, nie ma też zmysłu eklezjalnego, jednak w jego przekazie uderza psychologia głębi, doświadczenie żarliwej modlitwy oraz wnikliwość egzegezy biblijnej ${ }^{48}$. Należy mieć nadzieję, że zasygnalizowane tutaj kwestie i wątki staną się dla czytelnika pomocą w dalszych poszukiwaniach i bardziej wnikliwych badaniach interesującego zagadnienia mistyki światła w ujęciu Pseudo-Makarego.

BibLIOgRAFIA

\section{Źródła}

Baehrens W.A. (red.), Origenes Werke (GCS 8; Leipzig: J.C. Hinrichs'sche Buchhandlung, 1925).

Collectio I: Sermones LXIV Makarios/Symeon. Reden und Briefe, Die Sammlung I des Vaticanus Graecus 694. I. Logoi 1-29; II. Logoi 30-64 (red. H. Berthold) (GCS I/1-2; Berlin: AkademieVerlag, 1973). 
Collectio II: Homiliae spiritales Die 50 geistlichen Homilien des Makarios (red. H. Dörries - E. Klostermann - H.M. Kroeger) (PTS 4; Berlin: De Gruyter, 1964 ) (PG 34, 449-822).

Collectio III: Sermones XLIII Neue Homilien des Makarius/ Symeon (red. E.Klostermann - H. Berthold) (TU 72; Berlin: Akademie-Verlag, 1961) = Pseudo-Macaire, Oeuvres spirituelles. I. Homélies propres à la Collection III (tt. V. Desprez) (SCh 275; Paris: Cerf, 1980).

Collectio IV: ms. Parisinus Graecus $973(X)$ [26 Logoi powtórzone w Collectio I] = 150 chaptires de saint Macaire (tł. J. Touraille) (Philocalie des Pères Neptiques 5; Bellefontaine: Abbaye de Bellefontaine, 1984).

Grzegorz z Nyssy, Homilie do Pieśni nad Pieśniami (tł., wstęp, przypisy M. Przyszychowska) (ŹMT 43; Kraków: WAM, 2007). Grzegorz z Nyssy, In Canticum Canticorum (red. H. Langerbeck) (Gregorii Nysseni Opera 6; Leiden: Brill, 1960).

Grzegorz z Nyssy, In Canticum Canticorum Homiliae. Hom. 2 (PG 44, 805 CD. 808B).

Orygenes, Komentarz do Pieśni nad Pieśniami (Orygenes, Komentarz do Pieśni nad Pieśniami. Homilie o Pieśni nad Pieśniami [tt. S. Kalinkowski] [Kraków: WAM, 1994]).

Pseudo-Macarius, The Fifty Spiritual Homilies and the Great Letter (red. G.A. Maloney) (New York: Paulist Press, 1992). Pseudo-Makary/Symeon Egipski, „Homilia IV (49). Chrześcijanie powinni z gorliwością i roztropnością biec w wyścigu życia na arenie tego świata (Collectio I et II, CPG 2410 et 2411: Cursum stadii huius mundi attente et accurante absolvere oportet christianos)" (tłum. A. Jasiewicz), Vox Patrum 30/55 (2010) 903-917.

Strothmann W. (red.), Die syrische Überlieferung der Schriften des Makarios. I-II. Syrischer Text und Übersetzung (Wiesbaden: Harrassowitz, 1981).

Strothmann W. (red.), Schriften des Makarios/Symeon unter dem Namen des Ephraem (Wiesbaden: Harrassowitz, 1981). 


\section{Opracowania}

Crouzel H., Orygenes (tłum. J. Margański) (Bydgoszcz: Homini, 1996).

Deschepper J.-P., [rec.] „Pseudo-Macaire, Oeuvres spirituelles.

I. Homélies propres à la Collection III (wstęp, th. i komentarz

V. Desprez) (SCh 275; Paris: Cerf, 1980)", Revue Philosophique de Louvain. Quatrième Série 82/54 (1984) 269-270.

Desprez V., Początki monastycyzmu (tł. J. Dembska) (ŹM 22; Kraków: Tyniec, 1999).

Guillaumont A., „Situation et signification du 'Liber Graduum' dans la spiritualité syriaque", Symposium Syriacum 1972, célébré dans les jours 26-31 octobre 1972 à l'Institut Pontifical Oriental de Rome. Rapports et Communications (Orientalia Christiana Analecta 197; Rome: Pontificium Institutum Orientalium Studiorum, 1974) 311-322.

Gribomont J., „Macaire (Syméon)”, Dictionnaire encyclopédique du christianisme ancien (red. A. Di Berardino) (Paris: Cerf, 1990) II, 1509-1510.

Miquel P., „Les caractères de l'expérience spirituelle selon le Pseudo-Macaire", Irénikon 39 (1966) 497-513.

Maloney G.A., Why Not Become Totally Fire? Power of Fiery Prayer (New York and Mahawah, N.J.: Paulist Press, 1989).

Przeździecki J., „Anapausis w pismach Pseudo-Makarego”, Vox Patrum 28/52 (2008) 893-906.

Szczur P., „Symeon z Mezopotamii, Makary z Mezopotamii, Pseudo-Makary", Encyklopedia katolicka (red. E. Giglewicz et al.) (Lublin: Towarzystwo Naukowe KUL, 2013) XVIII, 1308-1310.

Klostermann R.A., Die slavische Überlieferung der Makariusschriften (Göteborg: Elander, 1950).

Ks. Andrzej Uciecha, kapłan archidiecezji katowickiej, odbył studia pod kierunkiem ks. prof. Edwarda Stańka (PAT, Kraków), ks. prof. Wincentego Myszora (UKSW, Warszawa) i prof. Marie- 
Josepha Pierre'a (Institut Catholique de Paris, École Pratique des Hautes Études, Paryż), doktor nauk humanistycznych w zakresie historii (rozprawa doktorska Ascetyczna nauka w Mowach Afrahata, 2000), doktor habilitowany nauk teologicznych w zakresie patrologii na podstawie rozprawy Polemikaśw. Efrema z manicheizmem $w$ Refutationes i dorobku naukowego (2010), adiunkt Katedry Teologii Patrystycznej i Historii Kościoła Wydziału Teologicznego UŚ (od 2001), prowadzi badania naukowe w zakresie literatury patrystycznej języka syryjskiego (św. Efrem Syryjczyk, Afrahat), członek Sekcji Patrystycznej przy Komisji Episkopatu Polski ds. Nauki Katolickiej i Komisji Bizantynologicznej Komitetu Nauk o Kulturze Antycznej PAN, sekretarz redakcji wydawnictwa Studia Antiquitatis Christianae. Series Nova. E-mail: andrzej.uciecha@wp.pl 